\title{
CAIRO'S AL-AZHAR PARK: MILLENIUM DEVELOPMENT GOALS ETCHED IN GREEN
}

\author{
Khaled el-Khishin ${ }^{1}$ \\ Faculty of Engineering, \\ BENHA UNIVERSITY, EGYPT
}

\begin{abstract}
This paper sheds light on a grand new park that has been inaugurated in Cairo on March $25^{\text {th }}, 2005$. The park is just one element of a far-reaching urban renewal scheme which seeks to restore a slum of Islamic Cairo where many cultural assets and monuments exist. The ambitious project, which has galvanized the nation, has drawn on the resources of international, national and local agencies in addition to grassroots organizations. Upon completion, the integrated development project is envisaged to rehabilitate many dwellings, monuments and urban spaces, in addition to creating employment, drawing droves of tourists and improving the quality of life in its vicinity. Thus, the impact of the project will most certainly fulfill some of the Millennium Development Goals (MDGs) set forth by the UN at the turn of the century.
\end{abstract}

Keywords: Park, Millennium Development Goals, Urban Growth

\section{INTRODUCTION}

The city of Cairo, home to some 17 million inhabitants, has arguably the least amount of green space per capita compared to other major metropolises of the world. In 1984, a major conference entitled, "The Expanding Metropolis: Coping with the Urban Growth of Cairo," was held in the Egyptian capital at the behest of the Aga Khan Award for Architecture. The conference culminated in very valuable deliberations and research; however, its most tangible outcome was a commitment by HH Prince Karim Aga Khan -leader of the Ismaili sect and descendant of the Fatimids who ruled Egypt between the years 969-1171- to donate a park to the city of his ancestors. The choice of the park's site, therefore, came as no surprise. The al-Darrassa site, formed of mounds of debris and garbage accumulated over 5 centuries, covered parts of Cairo's Ayyubid wall. Beyond the wall, to the west, lies the Darb al-Ahmar slum, part

' Dr. Khaled el-Khishin is a Professor of Urban Planning. 
of Fatimid Cairo. To the east, lies the famous Mamluk City of the Dead with its many mausoleums and minarets. Finally, to the south of the site, lies one of Cairo's eternal landmarks: Saladin's Ayyubid Citadel.

This paper will review the Millennium development Goals (MDGs), the history of the project, the challenges which faced it, the park's different components, and finally, the project's impact on a developing metropolis such as Cairo. The synthesis section will highlight questions deemed important for the replication of the project in other contexts.

\section{THE UN MILLENIUM DECLARATION: A REVIEW OF MDGS}

The UN Millennium Declaration made public in the year 2000 strove to improve the lives of at least 100 million dwellers by the year 2020 , by realizing eight goals. Appropriately labeled MDGs, they are the following; eradicating extreme poverty by halving the proportion of people suffering from hunger; achieving universal primary education; promoting gender equality and empower women by increasing their enrolment in primary education; reducing the mortality rate of children under 5 years of age by $65 \%$; decreasing maternal mortality rates by up to $75 \%$; reducing the incidence of HIV/AIDS and other pandemics; ensuring environmental sustainability by incorporating the environment in national and urban policies; And, finally developing $a$ global partnership for the development of cross-cultural exchanges, information, new technologies ...etc (Moreno, 2005).

\section{THE PARK SITE: CHALLENGES AND PROSPECTS}

The park site was originally a barren expanse of saline soil, which was used as a garbage dump for 500 years. More recently, the site was used as a storage area for a governmental construction company, in addition to the stables of the Cairo mounted police (Lindsey \& el-Amrani, 2005). In the 1990s, moreover, the Cairo Wastewater Authority constructed three large water tanks 80 meters in width and 16 meters in breadth on the site to provide clean water to the local neighbourhoods. Claiming the site for the park, therefore, involved overcoming bureaucratic hurdles, which delayed the launching of the project till the year 2000. Other challenges posed by the site included its proximity to one of the poorest slums in Cairo, al-Darb al-Ahmar. The 200,000 residents of Darb alAhmar had been left to fend for themselves over the years resulting in low literacy, lack of awareness, and gender inequality, a high crime rate and poor sanitary conditions. The 1992 earthquake, moreover, damaged many of the 
valuable monuments existing in the slum. For instance, minarets of some mosques were toppled, while medieval schools suffered from serious cracks. Finally, the salinity of the soil at the site of the park was a major challenge which required testing plant species in the American University of Cairo's desert nursery, located some 100 Kilometres away, before planting the successful ones in the park.

By 1996, and in response to such challenges, the project of the park developed beyond the initial idea and expanded to include, first, the rehabilitation of the Ayyubid wall; second, the restoration of selected monuments and urban spaces in Darb al-Ahmar, and third, the upgrading of housing stock along the Ayyubid wall. The initiation of an ambitious socio-economic development program, which aimed to alleviate poverty and improve the quality of life in Darb alAhmar, was also included to guarantee the sustainability of the project. The aforementioned socio-economic development program, include the extension of micro-credit finance, a health care component, and apprenticeship opportunities (AKDN, 2005a).

\section{THE MODE OF INTERVENTION}

At the outset, The Aga Khan Trust for Culture was faced with three scenarios for upgrading Darb al-Ahmar. The first scenario would have entailed radical intervention and the relocation of swathes of population and eradication of dilapidated premises. The second laissez faire scenario would have left market forces to exercise their full weight, thus resulting in new developments that are totally alien to the existing fabric. The third scenario, which was ultimately chosen and implemented, called for educated and incremental interventions especially in the vicinity of the Ayyubid wall. The intention of this scenario was to promote an exercise in social engineering. According to this scenario, residents' lives, and not only the physical structures, were earmarked for restoration! Only fairly recently, did the Egyptian Council for Antiquities give up its demand that the Ayyubid wall be "freed" from the onslaught of residential development in its immediate vicinity. This was a major decision that helped kick start the restoration of dilapidated stock along the wall (ElMikawy, 2005).

\section{THE PROJECT'S COMPONENTS: BALANCE SHEETS TO DATE}

The $\$ 30$ million project has made strides since its inception. On March $25^{\text {th }}$ 2005, al-Azhar Park was opened to the public. The park covers 30 hectares and 
is furbished by 655,000 plants, out of a total of 2 million plants, which have been propagated in a special nursery and will eventually be transplanted in the park (see figure 1 to 3 ). The amenities of the park include two upscale restaurants, an artificial pond, children's playgrounds, an amphitheatre, observation decks, and a central 8 meters wide promenade flanked by royal palms (AKTC 2003). The processional promenade links both ends of the park and provides a powerful visual link to Saladin's Citadel. Furthermore, the western hillside leading to Darb al-Ahmar is covered with colourful flowers and succulent plants.

Beyond the park, the excavation of 1.5 million cubic meters of debris which buried the 1.5 kilometer long Ayyubid wall has been completed, and the restoration of the latter is proceeding in earnest. A British designer is, currently conceiving the lighting scheme of the wall. Under permitting circumstances, the interior chambers of the wall and the towers will be open for the public (AKDN 2005b). In tandem, three monumental buildings in Darb al-Ahmar are being restored. These are the Khayrbek complex (consisting of a $13^{\text {th }}$ century palace, a mosque and an Ottoman house), the Umm Sultan Shaaban mosque and the Darb Shoughlan school.

As for the residential stock, a sample of houses has been rehabilitated. This marks the start of an ambitious program estimated to rehabilitate 50 houses per year till 2009 at an overall cost of $\$ 4$ million. Furthermore, the employment component of the project has been boosted by the disbursement of 425 loans, of which $53 \%$ went to retail, $35 \%$ to cottage industries and $12 \%$ to the service and transportation sectors (AKTC 2005). Job training and employment are now offered in park maintenance, landscaping, shoemaking, furniture manufacturing and souvenir products. Apprenticeships in automobile maintenance, computers, traditional construction techniques, carpentry and office skills are also available for young men and women.

Finally, basic social services relating to health, education and solid waste disposal have been upgraded. Much of the upgrading effort is credited to, first, the construction of a Family Health Development Centre offering maternal and clinical care; second, the establishment of vocational, administrative, and literacy courses; and third, close coordination with the responsible solid waste company as well as with volunteers from Darb al-Ahmar who engage in periodic awareness campaigns (Ibid.). 


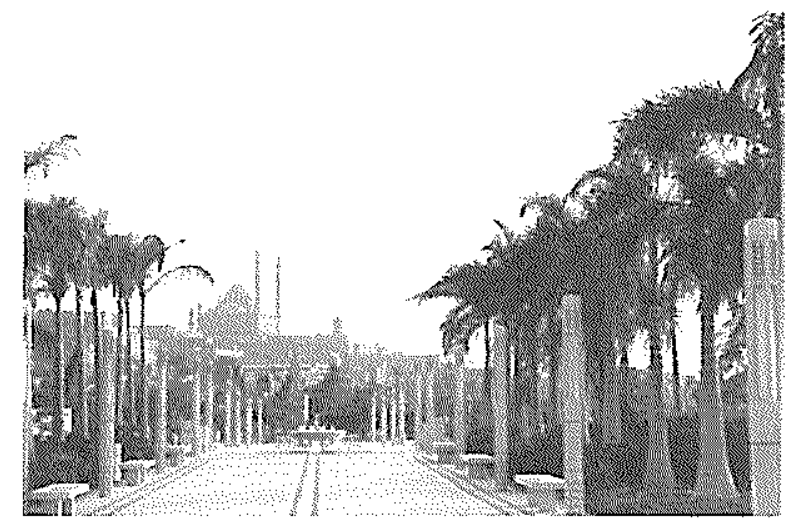

Figure 1

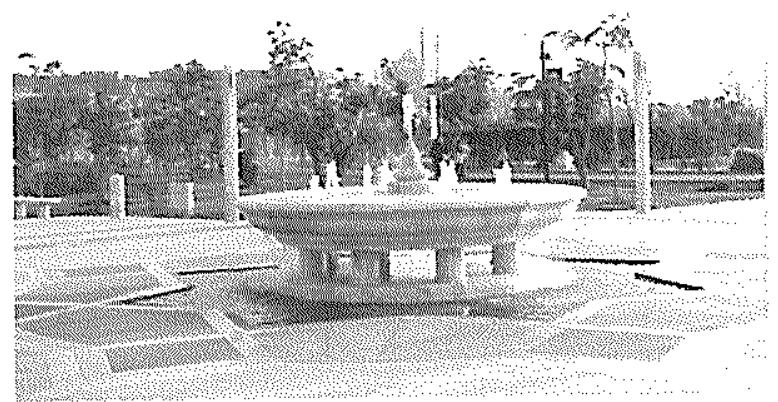

Figure 2

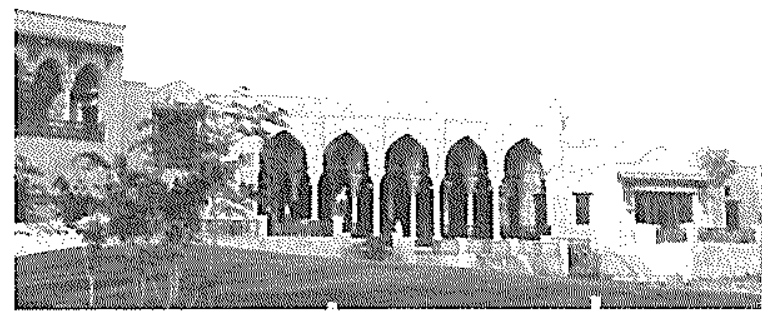

Figure 3 


\section{MAJOR CONTRIBUTORS TO THE PROJECT}

In addition to the main provider, the Aga Khan Trust for Culture, the project owes its existence to a collaborative effort of international, national, local and grassroots organizations. International contributors include the Ford Foundation, the World Monuments Fund (providing grants for monument restoration), the Egyptian Swiss Development Fund (project initiation grant), the American University in Cairo (offering its nursery for propagating the flora of the park), and finally, Egypt's Social Development Fund. National contributors include the Egyptian Ministry of Culture and the Supreme Council of Antiquities. The Governorate of Cairo contributed its resources at the local level in tandem with multiple NGOs and the grassroots including residents of Darb al-Ahmar (Ibid.).

\section{ANALYSIS: THE PROJECT AS A CATALYST FOR THE REALIZATION OF MDGS}

Once complete, the integrated development of the park and rehabilitation projects will bring many MDGs to the city level, since it situates the targets in a local context (Mehta, 2005). Currently, the integrated project realizes three of the MDGs reviewed in section 3 of this paper. These are; the eradication of extreme poverty through the extension of micro-credit and employment generation; ensuring environmental sustainability through the rehabilitation, and raising the awareness, of cultural and natural assets; and finally, the promotion of global/local partnerships and networks by pooling the resources of contributors. To a lesser extent, the health care component of the socioeconomic aspect of the project will also help realize the goals of decreasing child mortality rates and promoting gender equality.

That said, the project has had a tremendous impact on slum upgrading efforts in Cairo. First, the project highlighted the importance of political will at all levels of the Egyptian and donors' hierarchies. Second, implementation of the project promoted innovative governance. Third, the project encouraged the residents of Darb al-Ahmar to think of creative local solutions to their problems and to engage in participatory governance. It also reaffirmed traditional cultural values and the concept of ownership, which Auclair (2005) so aptly refers to as "shared responsibility.", on top of setting targets which could easily be monitored and evaluated throughout the implementation phase. The project strengthened existing institutions at the neighbourhood level, and pioneered new ones thus bolstering capacity building at the community level. Finally, it 
created effective partnerships, established valuable socio-cultural databases, and initiated top-bottom and bottom-up learning processes.

\section{SYNTHESIS: WHAT NEXT?}

Emulating the success of al-Azhar's integrated development project elsewhere in Cairo, or indeed in any other metropolis, depends on whether the following questions are addressed properly. Can enough political will be mobilized at all levels with the explicit aim of realizing a marked improvement in slums? How is this will incorporated in urban policy? Is the right policy, legal and regulatory (finance, tenure, norms and standards) framework in place? Are the necessary institutions and human resources up to the challenge of sustaining the upgrading effort over the period of the project and beyond? And, finally, can the dividends of successful developments be invested to generate momentum in other areas less visible and notably deprived from cultural assets?

\section{REFERENCES:}

Aga Khan Development Network (AKDN). 2005(a). "Inauguration of al-Azhar Park." Press Release, March $25^{\text {th }} 2005$. (www.akdn.org.)

Aga Khan Development Network (AKDN). 2005 (b). "Aga Khan and Madame Mubarak Inaugurate al-Azhar Park: the Park as a Catalyst for Social Economic and Cultural Renewal." Press Release, March $25^{\text {th }} 2005$. (www.akdn.org.)

Aga Khan Trust for Culture (AKTC). 2005. Cairo: Urban Regeneration in the Darb al-Ahmar District. Historic Cities Support Programme. Artemides Edizione, Rome, Italy.

Aga Khan Trust for Culture (AKTC). 2003. The Azhar Park Project in Cairo and the conservation and Revitalisation of Darb al-Ahmar. Historic Cities Support Programme. Impremeries Réunies Lausanne s.a., Switzerland.

Auclair, C. 2005. "The Millennium Declaration and the Habitat Agenda." Habitat Debate, September vol. 11 no 3, p. 9. UN-Habitat. Nairobi, Kenya.

Bazoglu, N. 2005. "The need for a more ambitious target." Habitat Debate, September vol. 11, no 3, p.8. UN-Habitat. Nairobi, Kenya.

El-Mikawi, M. 2005. Informal Interview with al-Azhar Park Manager. October $14^{\text {th }}$.

Lindsey, U \& el-Amrani, Iskander. 2005. "Dream of Green." (www.cairomagazine.com.) 
Mehta, D. 2005. "Bringing the goals to city level." Habitat Debate, September Vol. 11, no 3, p. 10. UN-Habitat. Nairobi, Kenya.

Moreno, E. 2005. "How far is the world from the slum target?" Habitat Debate, September Vol. 11, no 3, p.4. UN-Habitat. Nairobi, Kenya. 